\title{
Sandy sediments as active biogeochemical reactors: compound cycling in the fast lane
}

\author{
Carlos Rocha* \\ Biogeochemistry Research Group, CIMA/IMAR, Universidade do Algarve, Campus de Gambelas, 8000 Faro, Portugal \\ Present address: Trinity College Dublin, School of Natural Sciences, Dublin 2, Ireland
}

\begin{abstract}
The concept of assessing benthic biogeochemical standing stocks as an ecologically relevant parameter has been challenged by one of a dynamic nature: in sands, low standing stocks may mean low carbon burial efficiency due to rapid turnover aided by advective interfacial flows. This concept suggests that a large, diverse and very adaptable population of microbes is present in sands, and that these have a previously unforeseen biogeochemical importance. This view has profound consequences for the scientific outlook on the ecological role of permeable sediments and on the methodological strategies used in the study of coastal ecosystems. Based on a review of the current literature and results gathered at a coastal setting, progress within this new paradigm is examined and underlying questions are speculated upon. The evidence so far shows that, in permeable sediments and at timescales of seconds to a few hours, the dynamics of advective flow to a large extent control microbial diversity, the rates of microbial processes, the size of organic and inorganic pools, and even their respective changes. The importance of obtaining further information on the microbial diversity, the structure of different communities present in sands and their link to biogeochemical function arises from recent field studies. What is also clear from the available evidence is that only a combination of different techniques and approaches, some of which are under development on the fringes of previously almost water-tight research areas, will further understanding of the important functional role of microbial populations in benthic ecosystems.
\end{abstract}

KEY WORDS: Permeable sediments - Sand · Biogeochemistry · Carbon cycling · Coastal zones · Shelf zones

Resale or republication not permitted without written consent of the publisher

\section{INTRODUCTION}

\section{Coastal shelf seas as biogeochemical hotspots}

The flow of carbon and nitrogen from land to sea is largely intercepted by benthic microbial communities in coastal sediments. Hence, the coastal ecotone is a transport-reaction node, one that modulates elemental fluxes between continental ecosystems, including human settlements, the sea and the atmosphere (e.g. Rabouille et al. 2001, Middelburg et al. 2005). Observable effects of this functional role include support for higher rates of primary production in coastal waters. These are promoted by higher nutrient availability
(Mackenzie et al. 2002), on the one hand introduced by river discharge, diffuse sources and benthic remineralization, and, on the other hand, by upwelling water masses which deliver remineralized inorganic solutes produced by the breakdown of organic compounds settled in the continental slope and deep sea. Consequently, $30 \%$ of the total anthropogenic $\mathrm{CO}_{2}(118 \pm 19 \times$ $10^{15} \mathrm{~g} \mathrm{C}$ ) sunk into the ocean via the biological pump is found over the continental shelves (depth $<200 \mathrm{~m}$ ), and $50 \%$ above the $400 \mathrm{~m}$ isobath (Sabine et al. 2004). An important consequence of the combination of shallow depths with all the intersecting POC and PON transport pathways is that the efficiency of carbon transfer into underlying sediments is higher. Accordingly, the conti- 
nental shelf is an important burial ground for organic matter, with $>90 \%\left(>1 \times 10^{14} \mathrm{~g} \mathrm{C} \mathrm{yr}^{-1}\right)$ of the global suspended load being buried there (Hedges \& Keil 1995). In addition, larger photic zone to water column depth ratios make the journey of fresh POM into the sediment a shorter one, thus guaranteeing that mineralization substrates arrive at the sediment-water interface in a very fresh and labile condition.

\section{Paradigm shift}

The importance of the continental fringe and shelf in the global carbon cycle cannot be overemphasized, particularly since the coastal zone will bear the brunt of human occupation and climate-related changes for decades to come (e.g. Crossland et al. 2005). However, while recognizing the importance of shallow-water carbon and nutrient recycling in the global budget, the marine scientific community has nurtured a longstanding paradigm, one arising from the observation that high benthic (re)mineralization rates were directly correlated to organic matter content. This observation somehow reinforced the notion that the size of the benthic organic pool determined the functional importance of coastal sediments. The failure to effectively test the previously mentioned correlation for causation, mainly due to methodological constraints, led to the widely accepted, but misguided, view whereby low or residual organic content of sediment beds was a consequence of their low biogeochemical importance.

However, the effectual cause for the observed correlation was the zeroth-order kinetics of aerobic mineralization: with increasing standing stocks, the breakdown of organic matter would only be dependent on oxidant exposure time and not directly on carbon loading. Hence, when carbon loads are significant and solute transport is physically limited (i.e. by diffusion at the Diffusive Boundary Layer), hindering the supply of oxygen and other terminal electron acceptors from the water column to the sediment, a fraction of the loaded carbon might escape mineralization and be preserved by burial (Betts \& Holland 1991). Because shorter exposure time to oxidants, and oxygen in particular, leads to higher carbon burial efficiency (Hartnett et al. 1998), higher accretion rates will shorten the exposure of organics to oxidants under transport-limited conditions and thus increase carbon burial.

The role oxygen plays in carbon preservation has been intensely debated because oxygen is the primary electron acceptor for organic matter decomposition and it has been well established that oxygen-deficient zones are sites of high carbon burial efficiency (Hartnett \& Devol 2003). The link between organic content and biogeochemical importance was further stressed by the higher sediment-water interface concentration gradients found at muddy sites, which led to larger cross-interface fluxes as calculated by Fick's first law when compared with sandy sediments: under steadystate conditions, high fluxes balanced high reaction rates, so a large organic pool equated large biogeochemical reaction rates. What got lost in translation to a large section of the scientific community was that the reverse was not necessarily true. The traditional concept of a passive sediment bed, e.g. one receiving the input of settling organic matter and inorganic particles, subsequently buried by continuous accretion and mixing by infauna, was thus strengthened.

Sands, with an organic content 1 to 2 orders of magnitude lower and primarily consisting of low surface area particles compared to muds, apparently provide fewer possibilities for microbe attachment and consequently became (unsurprisingly) a bleak field of study for the biogeochemist and the microbial ecologist. The association between the burial efficiency of organic carbon, mineralization rates and the surface area of sediment particles was not to undermine traditional views until the seminal paper of Riedl et al. (1972) suggested that the entire volume of the ocean could be filtered through permeable sediment beds of coastal ecosystems in just $14000 \mathrm{yr}$.

Sands are permeable, thus permitting water to flow through the interstitial space when horizontal pressure gradients are present (Darcy 1856). Apart from hydraulic effects, gradients can arise from wave effects (Webb \& Theodor 1968, Rutgers van der Loeff 1981, Shum 1992), intersection of obstacles by boundary layer flow (Thibodeaux \& Boyle 1987), oscillating or rotational flow (Huettel \& Gust 1992) and density driven convection (Webster et al. 1996, Rocha 2000). Irrespective of the driving force, advective mass transfer seriously questioned the traditional view of the passive sediment bed. Contrary to the previous ethos, the low standing stocks of organic matter and inorganic mineralization by-products characteristic of permeable sediments might not, after all, reflect low biogeochemical importance. Instead, the relative organic poverty of sands could be due to rapid turnover. Experimental studies showing advective transport of oxygen into permeable beds (Booij et al. 1991, Ziebis et al. 1996), flow induced trapping of particulates by sand (Huettel et al. 1996, Rusch et al. 2001), and rapid removal of decomposition products (Huettel et al. 1998, Rocha 1998), all supported the hypothesis whereupon permeable sediments are sites of accelerated organic matter turnover (Boudreau et al. 2001, Huettel \& Webster 2001).

The global relevance of this maturing paradigm is related to the large areal cover of sands on continental shelves worldwide (Emery 1968). The concept of assessing benthic standing stocks as relevant when 
rating the functional importance of different sediment beds was thus challenged by one of a dynamic nature: low standing stocks could just mean low burial efficiency (large mass fluxes of oxidants and metabolites $\Rightarrow$ high microbial activity $\Rightarrow$ high turnover rates [mineralization] $\Rightarrow$ low residence time), suggesting that a large, diverse and very adaptable population of microbes could be present in sands and that these would have a previously unforeseen biogeochemical importance. This view would have profound consequences on (1) the scientific interest in the biogeochemical, functional role of permeable sediments, and (2) the methodological strategies used in the study of coastal ecosystems.

\section{COASTAL SANDS AS BIOCATALYTIC FILTERS}

\section{Overcoming methodological constraints}

The new paradigm suggests that most continental shelf sands constitute sites of enhanced organic carbon turnover and may act as 'biocatalytic filters' (Precht \& Huettel 2003) along the transport route linking continental ecosystems to the deep sea. By estimating that interfacial advection might drive one-third of the global benthic flux of oxygen and more than half of the phosphate flux, Meile \& Van Cappellen (2003) convincingly showed that enhanced solute transport may significantly enhance benthic-pelagic coupling worldwide. So far, the real magnitude of this enhancement is not measurable. Even though early flume studies demonstrated that advection of porewaters in permeable sediments supports complex 2- and 3-dimensional spatial and temporal biogeochemical zonation of the sandy seafloor (Forster et al. 1996, Ziebis et al. 1996, Huettel et al. 1998), in fact, the experimental characterization of solute transport and supporting reaction rates in sandy sediments is deterred by several obstacles: firstly, the pressure-induced flow pattern is 3dimensional, while reaction rates and particle and solute concentrations are mainly quantified by point measurements; secondly, techniques employed to obtain point measurements are usually intrusive in nature, thus disturbing the flow pattern to some degree; and finally, the pressure fields driving interfacial flows are highly dynamic and vary dramatically over short timescales depending on currents, waves and topography disturbing the local water flow. Accordingly, obtaining representative measurements under different conditions that combine all possible forcing functions is in effect not feasible with the present degree of knowledge.

Because advective interfacial flow controls the supply and removal of solutes and particulates in sands, the classical coring approach to quantify flux-defining concentration gradients, or the use of enclosed chamber techniques (Tengberg et al. 1995) are clearly inadequate to resolve fluxes coupling benthic reactivity and pelagic processes. Also, cutting off porewater flow by encasing sediment samples in cores or slurries to study reaction kinetics in the laboratory would hinder ongoing microbial reactions that relied on advective loading of metabolites. A new sampling methodology, one inclusive of the dynamic nature of interfacial advective flow, had to be developed.

Benthic flux chamber studies (Booij et al. 1991, Huettel \& Gust 1992) are a case in point. Glud et al. (1996a) showed how fluxes measured using enclosed chambers in permeable sediments ( $k$ [permeability] $>2 \times$ $10^{-12} \mathrm{~m}^{2}$ ) were dependent on stirrer-induced radial pressure gradients developing at the sediment-water interface. Porewater flow regimes similar to those found under microtopography-intersecting boundary layer flows were formed across the chamber as a consequence of centrifugal effects. Inasmuch as the study by Glud et al. (1996a) aimed to constrain field conditions for the use of chambers in benthic landers, it also showed that the porewater flow patterns created by chamber design and stirring rate could be predictable (Basu \& Khalili 1999). Flux chambers designed with this in mind were then deployed to study the influence of pre-defined advection regimes on total oxygen uptake in coarse sediments of the German Bight (Janssen et al. 2005a). For 3 different sites with contrasting grain sizes, the study by Janssen et al. (2005b) demonstrated that an advective regime imposed on the seabed promoted a $\sim 30 \%$ increase in the benthic metabolic rate, compared to control experiments without a pressure field.

Nonetheless, quantifying flux magnitudes and assessing microbial metabolism in natural settings depends on the extent of local interstitial circulation patterns, which could be co-driven by wave motion. Modeling studies demonstrated how, apart from being able to translate orbital motion to the porewater (Shum 1992), waves might also promote longitudinal oxygen gradients of the same order of magnitude as the vertical gradients measured in natural settings (Shum 1993). Even at low energy settings (waves $10 \mathrm{~cm}$ high) porewater velocities in shallow ripple fields, as measured in situ using fluorescent tracers (Precht \& Huettel 2004), demonstrated that advective transport through the sediment-water interface exceeded molecular diffusion by 3 orders of magnitude. In addition, wave tank studies (Precht \& Huettel 2003) showed that, under the combined effect of waves and unidirectional flow, ripple migration will promote dislocation of the porewater flow fields down current. This evidence is important in the context of benthic biogeochemical metabolism. Be- 
cause benthic mineralization is enhanced by repetitive oscillation of the redox boundary (Sun et al. 2002), translational movement of the oxic/ anoxic boundary due to ripple migration would expose organic matter to alternating redox conditions, thus promoting its degradation. Supporting the notion that metabolic rate distribution moved along with the ripple field, the 2-dimensional pattern of oxygen distribution as measured by planar optodes (Glud et al. 1996b, 2001) was shown to trail flow fields generated by migrating ripples (Precht et al. 2004). Anoxic upwelling zones under ripple crests were shown to alternate with oxygen-rich downwelling areas beneath ripple troughs. So formed, the redox field moved upcurrent with the migrating ripples, much like a conveyor belt. The intensity of this effect was dependent on the speed of ripple migration and on the sediment permeability. Above a threshold velocity and for a fixed permeability, instead of moving alternating redox boundaries, migrating ripples create a continuous oxidized layer, hence hindering the transfer of reduced solutes into the overlying water.

On the other hand, while experiments designed to isolate the forces driving porewater motion promote the understanding of the governing principles behind interfacial advection and its underlying role on the biogeochemistry of sands, they also illustrate the challenge of quantifying sediment-water fluxes under natural conditions. For instance, flux measurements over a rippled seabed need to be integrated over whole inflow and outflow areas along sampled sections of the seafloor. So far, the best candidate to fulfill this role is the eddy-correlation technique (Berg et al. 2003). This non-invasive method relies on contemporary measurements of fluctuating vertical velocities and rapidly changing oxygen concentrations within the measuring volume of an acoustic Doppler velocimeter by using a fast-response microsensor. While field testing of the method concentrated on oxygen as the target species (Berg et al. 2007, McGinnis et al. 2008), the procedure could be applied for any solute, as long as the response of the chemical sensor is able to discriminate concentration changes due to turbulent motion. Whilst the method is rapidly evolving into the standard for quantifying solute fluxes in dynamic aquatic environments, effective coupling between the measured fluxes and benthic reaction in porewater flow fields is far from being attained. The 2 main obstacles to progress in this direction that have persisted so far are the lack of (1) measurable constraints on the magnitude of flow penetration into a given sandy substrate, and (2) convincing in situ measurements of solute concentrations and reaction rates, coupled to the local flow field, supporting laboratory demonstrations.

Permeability is usually measured as a bulk sediment property under unidirectional flow. In reality it is a ten- sor, which means that its magnitude changes along the 3 orthogonal axes of space. While most of the experiments dealing with advective flow in laboratories have worked with sorted sands and the relevant modeling is based on the assumption of isotropic media, consolidated natural sediments are not characterized by these simplified conditions. Because flow within the porous matrix is conditioned by the magnitude of the permeability vector along the 3 directions, one of the most obvious shortcomings of research to date is the incapability of introducing this behaviour into observations and subsequent data analysis. For instance, consider the 2-dimensional permeability anisotropy - that is, $k_{z} / k_{X}$, the ratio between vertical and horizontal permeability - as determined in situ for the first time on a natural ripple field on the Ria Formosa coastal lagoon, Southern Portugal (Fig. 1), using a methodology yielding high-resolution vertical $\left(k_{z}\right)$ and horizontal $\left(k_{x}\right)$ permeability gradients (Rocha et al. 2005). The analysis shows that clear preferential flow pathways (vertical permeability dominant over horizontal on the trough and crest; Fig. 1, inset A), similar to that predicted by laboratory experiments, would develop under Bernoulli pressure gradients because the direction of the permeability vector determines the flow path (Darcy 1856). Although the sediment used in this experiment was coarse overall (median grain size $370 \mu \mathrm{m}$, bulk $k=1$ to $6 \times 10^{-11} \mathrm{~m}^{2}$ at a vertical scale length of $10 \mathrm{~cm}$ ), smaller-scale spatial inhomogeneities effectively restricted the potential for fluid motion through the sediment pores to the superficial $1 \mathrm{~cm}$ layer (Fig. 1, inset B, where below $1 \mathrm{~cm}$ depth, horizontal direction of the permeability vector is dominant, thus impeding vertical flows irrespective of pressure gradient). In this case study, mixing of particles and solute reactants could occur to ca. $5 \mathrm{~cm}$ depth on the left-hand side ripple (Fig. 1, inset A), but would not exceed the upper $1 \mathrm{~cm}$ layer on the right-hand side ripple (Fig. 1, inset B). This method not only reveals the large variability in permeability over small spatial scales in natural settings, but also provides clear evidence on the natural constraints to the filtering capacity of sandy sediments, required to adequately assess the global importance of the permeable seabed in organic carbon mineralization. Implications for the quantification of supported benthic reaction rates are obvious: sub-samples of sediment taken from field sites have to be subject to flow, with specific flow rates based on in situ measurements, and the natural constraints to the pore velocity presented by the natural permeability will eventually modulate derived reaction kinetics. Techniques such as those put forward by Polerecky et al. (2005), where oxygen consumption rates are measured by the stepwise insertion of microsensors in natural cores permeated by externally 
impressed flow, as well as the use of flow-through reactors to derive stoichiometric models of biogeochemical reactions and pathways (Laverman et al. 2006 and references therein) should become the standard for microbial reaction rate measurements in the laboratory.

\section{Reconciling laboratory studies with field studies}

Whilst field and laboratory studies are crucial in defining the role of interfacial exchange processes on the biogeochemical function of permeable sediments, prognostic capability will only be available when models reproducing the empirical data are developed. To date, modeling has provided important aides to research by assisting in the visualization of flow patterns that are difficult to reproduce in the laboratory (e.g. Meynsman et al. 2007), and also in the study of arrays of point measurements in field settings. While understanding of the governing principles and mapping of potentially active sediments advances (Forster et al. 2003), and technical bottlenecks for field-based quantitative research are overcome (see above), the modeling of porewater advection per se, as well as predicting its impact on the local or global geochemical cycles, remains a difficult task (Elliot \& Brooks 1997a,b, Packman \& Bencala 2000). Recent studies (Cardenas \& Wilson 2007a,b) investigated temporal coupling between turbulent water columns and topography-driven flow in permeable sediments, including composite flow arising from the presence of submarine groundwater discharge, using sequentially coupled numerical formulations. The 2-dimensional simulations suggest that interfacial flow patterns and boundary layer flow are correlated through water column eddies, which supports the use of the eddy-correlation technique (Berg et al. 2003) in coupling interfacial exchange to benthic reaction.

Nonetheless, models need to reconcile data describing the patterns of flow as well as concentration fields of target compounds, including relevant biogeochemistry. This perception can be illustrated by considering the distribution of chl $a$ in a natural ripple field, sampled perpendicularly to the ripple development in a coastal setting. The data presented in Fig. 2 show that chl a accumulates in the inflow and outflow areas of the ripple sequence, as postulated by theoretical and flume studies (Huettel et al. 1996, Precht \& Huettel 2003). In addition, the local flow pattern, calculated based on the knowledge of permeability microgradients (Rocha et al. 2005) and the pressure gradient at the interface (Elliot \& Brooks 1997a, Precht \& Huettel 2003), justifies this observation easily. This simple visual correlation shows that, although the local hydro- dynamics may prevent passive settling of pelagic microalgae, the inflows created by Bernoulli effects promote loading of carbon into the sediment. In addition, benthic primary production (note the chl a maxima in the outflow areas) may respond to rapid mineralization of newly buried organic matter. Thus, porewater flow pathways almost certainly link the supply of organic carbon to benthic primary production. Ripple migration will necessarily carry along some of the more recalcitrant particulates, as suggested by the presence of discrete concentrations ('blobs') of organic matter below the ripple line (left-hand side ripple). This effect may arguably create microbial microniches within migrating ripple fields, adding potential for the occurrence of heterotrophic denitrification, and may also extend the residence time of both active microalgae and less labile carbon within the sandy seafloor. For instance, Pilditch \& Miller (2006) found similar results in the laboratory under controlled flow conditions and different ripple geometries. Results from their study suggest that the combination of hydrodynamics and bedform heterogeneity lead to ripple-scale patchiness of organic matter input into coastal shelf sediments, along both the vertical and horizontal directional axes. Conversely, Huettel et al. (2007) found that algal decomposition rates in percolated sands were far from explaining the turnover rate of algal cells found in natural bedforms, hence implying that part of the cells are just temporarily retained within the sediment bed.

These results demonstrate that various patterns of carbon loading are established in natural ripple fields in response to porewater flow, caused by the intersection of bedforms with boundary-layer currents. Even though passive settling of particulates may not be possible under local hydrodynamic conditions, an active mechanism of carbon burial is present over sandbeds. However, within the ripple beds themselves, a series of microniches, potentially capable of sustaining both bacterial metabolism of a very diverse and adaptable nature, can potentially develop along the interstitial flow paths (Ishii et al. 2004, Bühring et al. 2005, Musat et al. 2006). Interesting questions develop as a consequence: What is the role of sands in providing nutrients to pelagic production temporarily stuck in migrating ripples? How do these algal cells benefit from the active biogeochemical environment - and conversely, how do they affect it? What is the feedback into the biological pump? How does this temporary burial affect microbial diversity and how does the latter correlate with different mixing regimes? With respect to the latter, Bühring et al. (2005) found different vertical scales of bacterial fatty acid distribution according to grain size, which could be an indication that bacteria are mixed deeper into coarser sediments. However, 


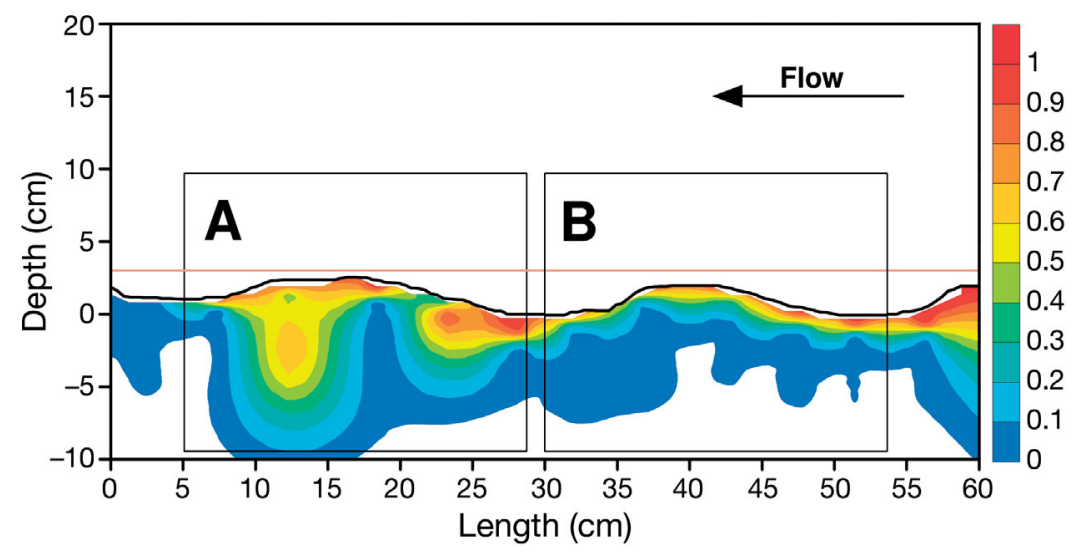

Fig. 1. Two-dimensional mapping of the microscale permeability anisotropy of a shallow sand ripple field in the Ria Formosa, Southern Portugal. Horizontal red line serves as reference relative to ripple height. Colour contours show the anisotropy as the ratio between local vertical permeability $\left(k_{z}\right)$ and horizontal permeability $\left(k_{x}\right)$. Kriging interpolation algorithm of 110 point measurements of $k_{x}$ and $k_{z \prime}$ aligned perpendicularly to ripple crests, with depth discrimination between 0.2 and $1.5 \mathrm{~cm}$, with greater resolution near the sediment-water interface. A value of 1 indicates identical orthogonal components of the permeability vector, ensuing in a preferential flow pathway with an angle of $45^{\circ}$ to the horizontal. Inset A: Local anisotropy field showing deep $(>5 \mathrm{~cm})$ potential flow pathways at ripple crest and trough, similar to sorted sand ripples used in flume experiments (Huettel et al. 1996, 1998, Ziebis et al. 1996). Inset B: Evidence of the natural spatial heterogeneity in preferential flow pathways. Note that, although inserted in the same ripple sequence as A, no available deep penetration capability is evident; instead, the permeable area is restricted to the ripple surface $(<1 \mathrm{~cm})$

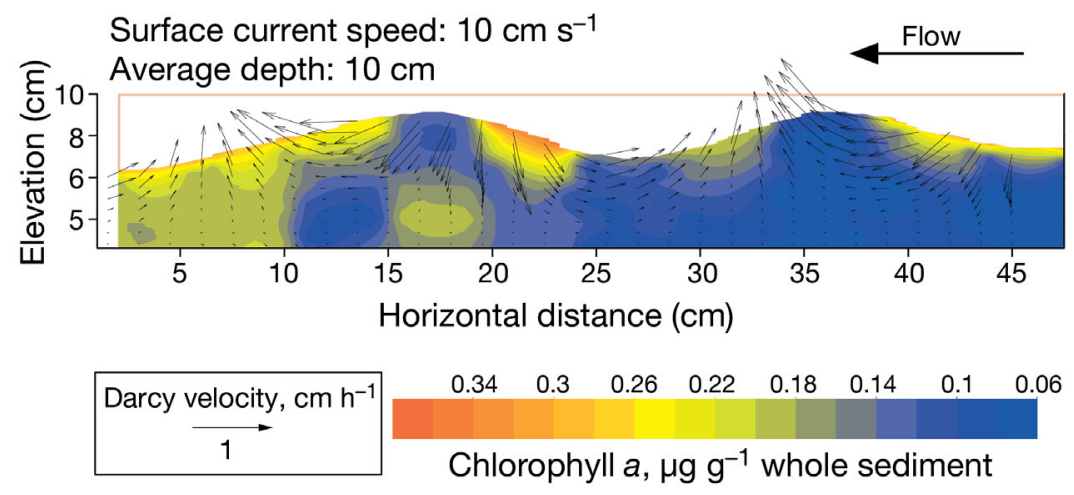

Fig. 2. Two-dimensional mapping of chl a distribution in a tidal ripple field in the Ria Formosa, sampled in December 2005. Superimposed is a 2-dimensional rendering of the Darcy flow vector field, calculated for an overlying water current speed of $10 \mathrm{~cm} \mathrm{~s}^{-1}$ and a depth of $10 \mathrm{~cm}$. Colour contours represent the interpolation of 140 point measurements of benthic chl a extracted from whole sediment samples in $80 \%$ acetone for $24 \mathrm{~h}$ in the dark at $-20^{\circ} \mathrm{C}$. Pigment concentrations determined according to Lorenzen \& Jeffrey (1980). Orthogonal components of the pore flow field were calculated individually by application of Darcy's law using the respective permeability vector component, measured according to Rocha et al. (2005) at each of the 140 sampling points. The horizontal pressure gradient driving the flow at the interface was calculated according to Elliot \& Brooks (1997a). For illustrative purposes, the 2 resulting orthogonal flow vector matrices where then summed on a point-by-point basis, thus rendering the plotted vector field. The flow magnitude is represented in a graphic depiction of a reference vector on the lower left (to scale) these authors, and Musat et al. (2006) also found that fluorescent in situ hybridization indicated the presence of large populations of sulphate-reducing bacteria, which indicates either that sulphate reduction is possible in oxic environments (see de Beer et al. 2005 for concomitant sulphate reduction rates), or conversely, that patterns of flow are not directly deducible from an apparent correlation between grain size and bulk permeability (see Figs. 1 $\& 2$ ). However, these findings beg the question of starvation/survival metabolism in benthic bacteria, and also suggest that our knowledge of the main biogeochemical reaction pathways in sands might be flawed, either because the relevant metabolic pathways are not known, or because benthic microbial diversity and structure is grossly underestimated. In addition, relevant issues develop with regard to the effects of particulate loading of sands on the flow pattern itself, because clogging, even temporary, will alter flow pathways by changing the permeability field. Our interpretation of interacting variables in sands is further complicated by the presence of bioturbating and bioirrigating infauna (Timmermann et al. 2006), which is sometimes present in large densities. While extension of flushing areas below the sediment-water interface seems to occur to a large extent (Volkenborn et al. 2007), the relative impact of the organisms themselves on the total flushing capacity of coastal shelf sands is largely unknown.

\section{CONCLUSIONS}

All evidence gathered so far shows that, in permeable sediments, it is the dynamics of advective flow that controls, to a large extent, microbial diversity and the rates of microbial processes (de Beer et al. 2005, Musat et al. 2006), the size of organic (Pilditch \& Miller 2006, Huettel et al. 2007) and inorganic pools and even their changes (Ehrenhauss et al. 2004, Janssen et al. 2005b), at timescales of 
seconds to a few hours. However, it is painfully clear from a cursory review of the literature that many coastal studies tend (still) to overlook this simple fact. At lagoons and intertidal sites, in particular, 'one-off' sampling strategies (e.g. a couple of core profiles taken in the laboratory, eventually complemented by static incubations, with results being extrapolated for a whole season or sediment morphological type) are unfortunately quite common in coastal ecosystem studies. When not exercised with cautionary principles that depend on ensuing data usage, this methodology will, necessarily, lead to gross errors in the proper identification of solute distributions and ongoing microbial processes. Under these conditions, the quantification of interfacial fluxes and supporting process rates, as well as their subsequent extrapolation to carbon and nutrient budgets in nature, would be severely compromised. Considering the already complex problems facing the scientific community, pressured to fathom the role played by coastal zones as a carbon sink and the ecological consequences of nitrate enrichment (Vitousek et al. 1997, Codispoti et al. 2001, Hulth et al. 2005, Codispoti 2006), such procedures amount to 'Cargo Cult Science' (Feynman 1974). 'Data' from these approaches should therefore be evaluated with extreme care.

Apart from the ongoing development of very promising non-destructive techniques for the visualization of microbial processes as they occur and real-time measurements of process rates (Kühl 2008, this Special), it is clear that the microbial diversity of sands, as well as the different metabolic pathways possible in this environment, have only very recently begun to be studied, and a strong effort must be made in this area. It is crucial that further information on microbial diversity and community structures present in sands and their link to biogeochemical function is obtained. More so than the technical developments, however, it is the crossdisciplinary outlook that is effectively showing more promise in advancing the understanding of the important functional role played by microbial populations in permeable benthic ecosystems, and this approach should be strongly supported.

Acknowledgements. I thank the organizers of the 10th European Microbial Ecology Symposium in Faro, September 2007, for inviting me to give a talk, and Paul del Giorgio and other editors of AME for extending that invitation to provide a contribution to this special issue. The work presented in this paper would not have been possible without the benefit of extended discussions with E. Epping, W. van Raaphorst, S. Forster, and E Koning, apart from the support and fieldwork of my research students J. Ibanhez, C. Leote, S. Polvora and C. Moita. The field work was supported by Project EMIR (Enhanced organic carbon mineralization rates in permeable sandy sediments) and by Project O-DOIS (POCTI/ CTA/
47078/2002), financed by the Portuguese Science and Technology Foundation (FCT). The comments of 2 anonymous reviewers were useful to improve the original manuscript draft.

\section{LITERATURE CITED}

Basu AJ, Khalili A (1999) Computation of flow through a fluid sediment-water interface in a benthic chamber. Phys Fluids 11:1395-1405

Berg P, Røy H, Janssen F, Meyer V, Jørgensen BB, Huettel M, de Beer D (2003) Oxygen uptake by aquatic sediments measured with a novel non-invasive eddy-correlation technique. Mar Ecol Prog Ser 261:75-83

Berg P, Røy H, Wiberg PL (2007) eddy correlation flux measurements: the sediment surface area that contributes to the flux. Limnol Oceanogr 52:1672-1684

Betts JN, Holland HD (1991) The oxygen content of ocean bottom waters, the burial efficiency of organic carbon, and the regulation of atmospheric oxygen. Palaeogeogr Palaeoclim Palaeoecol 97:5-18

> Booij K, Helder W, Sundby B (1991) Rapid redistribution of oxygen in a sandy sediment induced by changes in the flow velocity of the overlying water. Neth J Sea Res 28: 149-165

Boudreau BP, Huettel M, Forster S, Jahnke RA and others (2001) Permeable marine sediments: overturning an old paradigm. EOS Trans Am Geophys Union 82:133-136

Bühring SI, Elvert M, Witte U (2005) The microbial community structure of different permeable sandy sediments characterized by the investigation of bacterial fatty acids and fluorescence in situ hybridization. Environ Microbiol $7: 281-293$

Cardenas MB, Wilson JL (2007a) Hydrodynamics of coupled flow above and below a sediment-water interface with triangular bedforms. Adv Water Resour 30:301-313

Cardenas MB, Wilson JL (2007b) Exchange across a sediment-water interface with ambient groundwater discharge. J Hydrol 346:69-80

Codispoti LA (2006) An oceanic fixed nitrogen sink exceeding $400 \mathrm{TgNa} \angle 1$ vs the concept of homeostasis in the fixednitrogen inventory. Biogeosciences Discuss 3:1203-1246

Codispoti LA, Brandes JA, Christensen JP, Devol AH, Naqvi SWA, Paerl HW, Yoshinari T (2001) The oceanic fixed nitrogen and nitrous oxide budgets: moving targets as we enter the anthropocene? Sci Mar 65:85-105

Crossland CJ, Kremer HH, Lindeboom HJ, Crossland JJM, Le Tissier MDA (2005) Coastal fluxes in the anthropocene: the land-ocean interactions in the coastal zone project of the international geosphere biosphere programme. Springer, Berlin

Darcy H (1856) Les fontaines publiques de la Ville de Dijon. Dalmont, Paris

de Beer D, Wenzhofer F, Ferdelman TG, Boehme SE and others (2005) Transport and mineralization rates in North Sea sandy intertidal sediments, Sylt-Rømø basin, Wadden Sea. Limnol Oceanogr 50:113-127

> Ehrenhauss S, Witte U, Janssen F, Huettel M (2004) Decomposition of diatoms and nutrient dynamics in permeable North sea sediments. Cont Shelf Res 24:721-737

Elliott H, Brooks NH (1997a) Transfer of nonsorbing solutes to a streambed with bedforms: theory. Water Resour Res 33: 123-136

Elliott H, Brooks NH (1997b) Transfer of nonsorbing solutes to a streambed with bedforms: laboratory experiments. Water Resour Res 33:137-151 
Emery KO (1968) Relict sediments on continental shelves of the world. Am Assoc Pet Geol Bull 52:445-464

Feynman R (1974) Cargo cult science: some remarks on science, pseudo science, and learning how to not fool yourself-Caltech's 1974 commencement address. Eng Sci 73: $10-13$

Forster S, Huettel M, Ziebis W (1996) Impact of boundary layer flow velocity in oxygen utilization on coastal sediments. Mar Ecol Prog Ser 143:173-185

Forster S, Bobertz B, Bohling B (2003) Permeability of sands in the coastal areas of the southern Baltic Sea: mapping a grain-size related sediment property. Aquat Geochem 9: $171-190$

Glud RN, Forster F, Huettel M (1996a) Influence of radial pressure gradients on solute exchange in stirred benthic chambers. Mar Ecol Prog Ser 141:303-311

Glud RN, Ramsing NB, Gundersen JK, Klimant I (1996b) Planar optodes, a new tool for fine-scale measurements of two-dimensional $\mathrm{O}_{2}$ distribution in benthic communities. Mar Ecol Prog Ser 140:217-226

Glud RN, Tengberg A, Kühl M, Hall POJ, Klimant I, Holst G (2001) An in situ instrument for planar $\mathrm{O}_{2}$ optode measurements at benthic interfaces. Limnol Oceanogr 46: 2073-2080

Hartnett HE, Devol AH (2003) Role of a strong oxygendeficient zone in the preservation and degradation of organic matter: a carbon budget for the continental margins of northwest Mexico and Washington State. Geochim Cosmochim Acta 67:247-264

Hartnett HE, Keil RE, Hedges JI, Devol AH (1998) Influence of oxygen exposure time on organic carbon preservation in continental margin sediments. Nature 391:572-574

Hedges JI, Keil RG (1995) Sedimentary organic matter preservation: an assessment and speculative synthesis. Mar Chem 49:81-115

Huettel M, Gust G (1992) Solute release mechanisms from confined sediment cores in stirred benthic chambers and flume flows. Mar Ecol Prog Ser 82:187-197

Huettel M, Webster IT (2001) Porewater flow in permeable sediments. In: Boudreau BP, Jørgensen BB (eds) The benthic boundary layer: transport processes and biogeochemistry. Oxford University Press, Oxford, p 144-179

Huettel M, Ziebis W, Forster S (1996) Flow-induced uptake of particulate matter in permeable sediments. Limnol Oceanogr 42:309-322

Huettel M, Ziebis W, Forster S, Luther GW III (1998) Advective transport affecting metal and nutrient distributions and interfacial fluxes in permeable sediments. Geochim Cosmochim Acta 62:613-631

Huettel M, Cook P, Janssen F, Lavik G, Middelburg JJ (2007) Transport and degradation of a dinoflagellate bloom in permeable sublittoral sediment. Mar Ecol Prog Ser 340: 139-153

Hulth S, Aller RC, Canfield DE, Dalsgaard T and others (2005) Nitrogen removal in marine sediments: recent findings and future research challenges. Mar Chem 94:125-145

Ishii K, Mussmann M, MacGregor B, Amann R (2004) An improved fluorescence in situ hybridization protocol for the identification of bacteria and archea in marine sediments. FEMS Microbiol Ecol 50:203-212

Janssen F, Faerber P, Huettel M, Meyer V, Witte U (2005b) Pore-water advection and solute fluxes in permeable marine sediments (I): calibration and performance of the novel benthic chamber system Sandy. Limnol Oceanogr 50:768-778

Janssen F, Huettel M, Witte U (2005b) Pore-water advection and solute fluxes in permeable marine sediments (II): ben- thic respiration at three sandy sites with different permeabilities (German Bight, North Sea). Limnol Oceanogr 50:779-792

Kühl M, Polerecky L (2008) Functional and structural imaging of phototrophic microbial communities and symbioses. Aquat Microb Ecol 53:99-118

> Laverman AM, Van Cappellen P, van Rotterdam-Los D, Pallud C, J Abell (2006) Potential rates and pathways of microbial nitrate reduction in coastal sediments. FEMS Microbiol Ecol 58:179-192

Lorenzen CJ, Jeffrey SW (1980) Determination of chlorophyll in seawater. UNESCO Tech Pap Mar Sci 35

> Mackenzie FT, Ver LM, Lerman A (2002) Century-scale nitrogen and phosphorus controls of the carbon cycle. Chem Geol 190:13-32

$>$ McGinnis DF, Berg P, Brand A, Lorrai C, Edmonds TJ, Wüest A (2008) Measurements of eddy correlation oxygen fluxes in shallow freshwaters: towards routine applications and analysis. Geophys Res Lett 35:L04403. doi:10.1029/ 2007GL032747

Meile C, Van Cappellen P (2003) Global estimates of enhanced solute transport in marine sediments. Limnol Oceanogr 48:777-786

Meynsman FJR, Galaktionov OS, Cook PLM, Janssen F, Huettel M, Middelburg JJ (2007) Quantifying biologically and physically induced flow and tracer dynamics in permeable sediments. Biogeosciences 4:627-646

Middelburg JJ, Duarte CM, Gattuso JP (2005) Respiration in coastal benthic communities. In: del Georgio PA, Williams PJLeB (eds) Respiration in aquatic ecosystems - from single cells to the biosphere. Oxford University Press, Oxford, p 206-224

Musat N, Werner U, Knittel K, Kolb S and others (2006) Microbial community structure of sandy intertidal sediments in the North Sea, Sylt-Rømø Basin, Wadden Sea. Syst Appl Microbiol 29:333-348

Packman AI, Bencala KE (2000) Modelling methods in the study of surface-subsurface hydrologic interactions. In: Jones JB, Mulholland PJ (eds) Streams and ground waters. Academic Press, San Diego, CA, p 45-80

> Pilditch CA, Miller DC (2006) Phytoplankton deposition to permeable sediments under oscillatory flow: effects of ripple geometry and resuspension. Cont Shelf Res 26: 1806-1825

Polerecky L, Franke U, Werner U, Grunwald B, de Beer D (2005) High spatial resolution measurement of oxygen consumption rates in permeable sediments. Limnol Oceanogr Methods 3:75-85

Precht E, Huettel M (2003) Advective pore-water exchange driven by surface gravity waves and its ecological implications. Limnol Oceanogr 48:1674-1684

Precht E, Huettel M (2004) Rapid wave driven advective porewater exchange in a permeable coastal sediment. J Sea Res 51:93-107

Precht E, Franke L, Polerecky L, Huettel M (2004) Oxygen dynamics in permeable sediments with wave-driven porewater exchange. Limnol Oceanogr 49:693-705

Rabouille C, Mackenzie FT, Ver LM (2001) Influence of the human perturbation on carbon, nitrogen, and oxygen biogeochemical cycles in the global coastal ocean. Geochim Cosmochim Acta 65:3615-3641

Riedl RJ, Huang N, Machan R (1972) The subtidal pump: a mechanism for interstitial water exchange by wave action. Mar Biol 13:210-221

Rocha C (1998) Rythmic ammonium regeneration and flushing in intertidal sediments of the Sado estuary. Limnol Oceanogr 43:823-831

Rocha C (2000) Convective turnover on flooding of warm, 
permeable, intertidal sediments: the ecological importance of the convective turnover pump. J Sea Res 43:1-14

Rocha C, Forster S, Koning E, Epping E (2005) High-resolution permeability determination and two-dimensional pore water flow in sandy sediment. Limnol Oceanogr Methods 3:10-23

Rusch A, Huettel M, Forster S (2001) Bacteria, diatoms and detritus in an intertidal sandflat subject to advective transport across the sediment-water interface. Biogeochemistry 55:1-27

Rutgers van der Loeff MM (1981) Wave effects on sediment water exchange in a submerged sand bed. Neth J Sea Res 15:100-112

Sabine CL, Feely RA, Gruber N, Key RM and others (2004) The oceanic sink for anthropogenic $\mathrm{CO}_{2}$. Science 305: 367-371

Shum KT (1992) Wave-induced advective transport below a rippled water-sediment interface. J Geophys Res 97(C1): 789-808

Shum KT (1993) The effects of wave-induced pore water circulation on the transport of reactive solutes below a rippled water-sediment interface. J Geophys Res C 98: 10289-10301

Sun MY, Aller RC, Lee C, Wakeham SG (2002) Effects of oxygen and redox oscillation on degradation of cellassociated lipids in surficial marine sediments. Geochim

Submitted: January 7, 2008; Accepted: May 9, 2008
Cosmochim Acta 66:2003-2012

Tengberg A, de Bovée F, Hall P, Berelson W and others (1995) Benthic chamber and profiling landers in oceanographya review of design, technical solutions and functioning. Prog Oceanogr 35:253-292

Thibodeaux JL, Boyle JO (1987) Bed-form generated convective transport in bottom sediment. Nature 350: $53-55$

Timmermann K, Banta GT, Glud RN (2006) Linking Arenicola marina irrigation behavior to oxygen transport and dynamics in sandy sediments. J Mar Res 64: 915-938

Vitousek PM, Mooney HA, Lubchenco J, Melillo JM (1997) Human domination of earth's ecosystems. Science 277: 494-499

Volkenborn N, Polerecky L, Hedtkamp SIC, van Beusekom JEE, de Beer D (2007) Bioturbation and bioirrigation extend the open exchange regions in permeable sediments. Limnol Oceanogr 52:1898-1909

Webb JE, Theodor JL (1968) Irrigation of submerged marine sands through wave action. Nature 220:682-683

Webster IT, Norquay SJ, Ross FC, Wooding RA (1996) Solute exchange by convection within estuarine sediments. Estuar Coast Shelf Sci 42:171-183

Ziebis W, Huettel M, Forster S (1996) Impact of biogenic sediment topography on oxygen fluxes in permeable seabeds. Mar Ecol Prog Ser 140:227-237

Proofs received from author(s): July 7, 2008 